\title{
Neutrophil extracellular trap components increase the expression of coagulation factors
}

\author{
ASCENSIÓN MARÍA DE LOS REYES-GARCÍA*, ALEJANDRA AROCA*, \\ ANA BELÉN ARROYO, NURIA GARCÍA-BARBERA, VICENTE VICENTE, \\ ROCÍO GONZÁLEZ-CONEJERO and CONSTANTINO MARTÍNEZ
}

\begin{abstract}
Department of Hematology and Medical Oncology, Morales Meseguer University Hospital, Centro Regional de Hemodonación, University of Murcia, Instituto Murciano de Investigación Biosanitaria (IMIB-Arrixaca), 30003 Murcia, Spain
\end{abstract}

Received June 4, 2018; Accepted November 29, 2018

DOI: $10.3892 /$ br.2019.1187

\begin{abstract}
Neutrophil extracellular traps (NETs) represent an important link between inflammation and thrombosis. Here, the present study aimed to investigate the influence of the NET components, DNA and histone H4, on hemostatic gene expression. A further aim was to confirm the influence of $\mathrm{H} 4$ on the expression of tissue factor (TF) and investigate a potential effect of DNA, and to test the involvement of miR-17/92 and its paralog miR-106b-25 in this regulation. In HepG2 cells, the mRNA levels of factor VII and factor XII, which are crucial in the activation of the coagulation cascade, and of serpin family $F$ member 2 (encoding $\alpha 2$-antiplasmin) were significantly upregulated by DNA and H4; while the mRNA levels of factor $V$, which is essential for thrombin generation of protein $S$, a cofactor of protein $\mathrm{C}$ that also has the ability to inhibit the factor $\mathrm{X}$ activation pathway, and of serpin family $C$ member 1 (encoding antithrombin, the main endogenous anticoagulant) were significantly upregulated only by $\mathrm{H} 4$. H4 and DNA also provoked an increase in hepatocyte nuclear factor $4 \alpha(H N F 4 A)$ mRNA expression that could be responsible for the increase in the expression of certain coagulant factors. In THP-1 cells, it was also demonstrated that $\mathrm{H} 4$ caused an increase in TF mRNA while decreasing several of the microRNAs (miRNA/miRs) of the cluster miR-17/92, which may in part explain the increase in the expression of $T F$. The present results suggest the ability of NET components
\end{abstract}

Correspondence to: Professor Rocío González-Conejero or Dr Constantino Martínez, Department of Hematology and Medical Oncology, Morales Meseguer University Hospital, Centro Regional de Hemodonación, University of Murcia, Instituto Murciano de Investigación Biosanitaria (IMIB-Arrixaca), C/Ronda de Garay S/N, 30003 Murcia, Spain

E-mail: rocio.gonzalez@carm.es

E-mail: constant@um.es

*Contributed equally

Key words: microRNA, hemostasis, neutrophil extracellular traps, coagulation to alter the hemostatic balance and a possible involvement of $\mathrm{HNF} 4 \alpha$ and miRNAs in this regulation.

\section{Introduction}

Immunothrombosis is a recently recognized physiological process linking coagulation with innate immunity, of which the deregulation may constitute a crucial event in the development of thrombotic disorders (1). In this regard, this novel concept of thrombosis implies that certain immune innate cells serve a key role in thrombogenesis. Indeed, neutrophils are the first line of defence against invading pathogens and are established to be an essential component of the innate immune response; among the most important mechanistic factors involved in the hemostasis/inflammation crosstalk are neutrophil extracellular traps (NETs) (2). NETs consist of neutrophil web-like releasates formed by DNA, histones and other nuclear and cytoplasmic components including elastase, lactotransferrin, myeloperoxidase and calprotectin (3). To date, several stimuli able to induce NET release have been described. The most recognized is infection by pathogens (bacteria, fungi, viruses and protozoa), but other factors have been described that depend on the host including activated platelets, immune complexes and several inflammatory stimuli (4). Thus, the presence of NETs has been documented in several diseases with an elevated state of inflammation, including autoimmune diseases, atherosclerosis, vasculitis, cancer and several thrombotic disorders (5-9). In particular, it has been demonstrated that NETs promote thrombosis in vivo in mice models, and the implications of several of their components including DNA and histones have been widely studied $(10,11)$. Notably, stimulation of platelets with purified histones was sufficient to induce aggregation, and markers of extracellular DNA can be detected in plasma following a deep vein thrombosis episode $(10,11)$. The pathogenic role of histones in thrombosis was first proposed by showing that injection of histones in mice induced thrombotic lesions similar to those observed in severe sepsis (12). Indeed, histones have been reported to induce tissue factor (TF; also known as factor III) upregulation and thrombomodulin downregulation leading to a procoagulant phenotype, hence they are considered as damage-associated molecular patterns (DAMPs) (13). DAMPs are recognized as 
danger signals by Toll-like receptors (TLRs), but the molecular mechanism remains unclear (14-16). DNA is also deemed to be a DAMP, and it has been demonstrated that purified DNA may bind and activate proteins of the contact system, which involves factor XI and factor XII, and boost thrombin generation even in the absence of platelets (17). To date, the regulation of these DAMP-induced processes has remained unclear and, moreover, there is a lack of data on the effect of the different NET components on the expression of other hemostatic factors besides TF. In the present work, the aim was to evaluate the effect of DNA and histones on the expression of the following hemostatic factors genes: Factor V $(F 5)$, which is essential for thrombin generation catalysed by the prothrombinase complex (18) and necessary for the activation of prothrombin to thrombin by factor $\mathrm{Xa}(F 10)$ in the presence of $\mathrm{Ca}^{2+}(19)$; Factor VII (F7), a vitamin K-dependent protease with a crucial role in the initiation of the coagulation cascade (20); factor XII (F12), involved in the activation of the intrinsic coagulation pathway and the kallikrein-kinin system (21); PROC, which encodes protein $C$, a fundamental factor involved in the cleavage of factors Va and VIIIa (22); hepatocyte nuclear factor 4A (HNF4A), a member of the nuclear receptor superfamily of transcription factors and central to a complex regulatory network controlling hepatocyte differentiation and metabolism (23); serpin family C member 1 (SERPINC1), encoding antithrombin, the most important coagulation factor inhibitor, which is a serine protease inhibitor with both anticoagulant and anti-inflammatory action (24); serpin family F member 2 (SERPINF2), encoding the $\alpha 2$-antiplasmin, the primary physiological inhibitor of plasmin that is also able to inhibit other enzymes including elastase or trypsin (25); and finally, PROS1, which encodes protein S, a vitamin K-dependent glycoprotein that has the ability to inhibit factor $\mathrm{Xa}$ and act as a cofactor for the activated protein $\mathrm{C}$, taking part in the downregulation of coagulation (26). Furthermore, our group previously described the role of members of the microRNA (miRNA/miR)-17/92 cluster and its paralog miR-106b-25 as modulators of TF expression in a breast carcinoma cell line (MDA-MB-231) as well as in a monocytic leukemia cell line (THP-1) (27). Moreover, miR-19a has been previously described as an inhibitor of TF expression in breast cancer cells (16). Therefore, the current study also aimed to investigate if TF overexpression induced by histones and DNA, acting as DAMPs, may be mediated by miRNA regulation. The use of primary hepatocytes and monocytes would have been optimal to study the effect of NETs in the expression of coagulation factors. However, an inconvenience of these cells is the variability between individuals that may impact on the interpretation as a first approach (28). Thus, to minimize variability, the experiments were performed with cell lines that are well characterized and yield more homogeneous results (28).

\section{Materials and methods}

DNA purification. DNA was purified from the neutrophils of healthy donors isolated using Histopaque 1077 (Sigma Aldrich; Merck KGaA, Darmstadt, Germany). Briefly, neutrophils were purified from 12-ml whole blood samples and pelleted at $150 \mathrm{xg}$ for $15 \mathrm{~min}$ at room temperature. The neutrophil pellet was resuspended in Hank's balanced salt solution (supplemented with $\mathrm{Ca}^{2+}$ and $\mathrm{Mg}^{2+}$; Thermo Fisher Scientific, Inc., Waltham, MA, USA), and cells were counted with an automatic cell counter (Bio Rad Laboratories, Inc., Hercules, CA, USA). Purity was checked by flow cytometry, considering a cluster of differentiation CD11b+/CD14- population as neutrophils, and was always $>90 \%$ (data not shown). A BD Accuri ${ }^{\mathrm{TM}}$ C6 flow cytometer device (BD Biosciences, San Jose, CA, USA) was used with $\mathrm{CD} 11 \mathrm{~b}+$ fluorescein isothiocyanate-labelled (cat. no. 11-0118-42) and CD14-phycoerythrin-conjugate antibodies (cat. no. MHCD1417; Thermo Fisher Scientific, Inc.), applying $1 \mu \mathrm{l}(0.05 \mu \mathrm{g})$ antibody per $1 \times 10^{6}$ cells in a volume of $100 \mu \mathrm{l}$ [0.5\% PBS-bovine serum albumin (Merck KGaA), 2 mM EDTA], following the manufacturer's instructions. Neutrophils were acquired and analysed with the Accuri C6 software. DNA was obtained using a DNeasy kit (Qiagen GmbH, Hilden, Germany) following the manufacturer's protocol.

The donor subjects met the eligibility criteria: None of the subjects had a documented history of vascular disease, or a personal history of thromboembolic/hemorrhagic disease or cancer and all of them were $<65$ years old. All donors were enrolled after providing written informed consent. A total of 100 healthy subjects were included in the study. Participants were Caucasian, unrelated volunteers enrolled from the local blood donor center (Centro Regional de Hemodonación, Murcia, Spain). Their median age was 54 years (range, 46 to 63 years), and $33 \%$ were female. Enrollment was performed from January to April, 2017.

The study was approved by the Ethical Committee of Morales Meseguer University Hospital, Murcia, Spain (approval no. 20/14) and performed in accordance with the ethical standards laid down in the 1964 Declaration of Helsinki and its subsequent amendments.

Cell culture. The human liver carcinoma cell line HepG2 [American Type Culture Collection (ATCC), Manassas, VA, USA] was cultured in Eagle's minimum essential medium (MEM) supplemented with non-essential amino acids at $0.1 \mathrm{mM}$ and $10 \%$ fetal calf serum (FCS; all from Thermo Fisher Scientific, Inc.). The monocytic leukemia cell line THP-1 (ATCC) was cultured in ATCC-formulated RPMI-1640 medium with $10 \%$ FCS (Thermo Fisher Scientific, Madrid, Spain). Both cell lines were maintained at $37^{\circ} \mathrm{C}$ and $5 \% \mathrm{CO}_{2}$.

It was preliminarily verified by reverse transcription-quantitative polymerase chain reaction (RT-qPCR) that DNA dose-dependently induced TF mRNA expression in the THP-1 cells (tested at 0,25 and $50 \mathrm{ng} / \mu \mathrm{l}$; data not shown) and consequently the highest concentration was used for subsequent experiments. THP-1 cells $(500,000$ cells per well in 24-well plates) were activated with $50 \mathrm{ng} / \mu 1 \mathrm{DNA}$ from human neutrophils, or $20 \mu \mathrm{g} / \mu \mathrm{l}$ human recombinant histone H4 (New England BioLabs, Inc., Ipswich, MA, USA) as described by Kim et al (13); an equivalent volume of $\mathrm{H}_{2} \mathrm{O}$ was used as a negative control and $1 \mu \mathrm{g} / \mathrm{ml}$ Escherichia coli lipopolysaccharide (LPS; 0111:B4; Sigma-Aldrich) was used as a positive control of cell activation, all of which were diluted in Opti-MEM (Thermo Fisher Scientific, Inc.). After $2 \mathrm{~h}$ of incubation at $37^{\circ} \mathrm{C}$ and $5 \% \mathrm{CO}_{2}$, the THP-1 cells were harvested.

HepG2 cells ( $1 \times 10^{6}$ cells per well in 12 -well plates) were stimulated with DNA from human neutrophils or human 

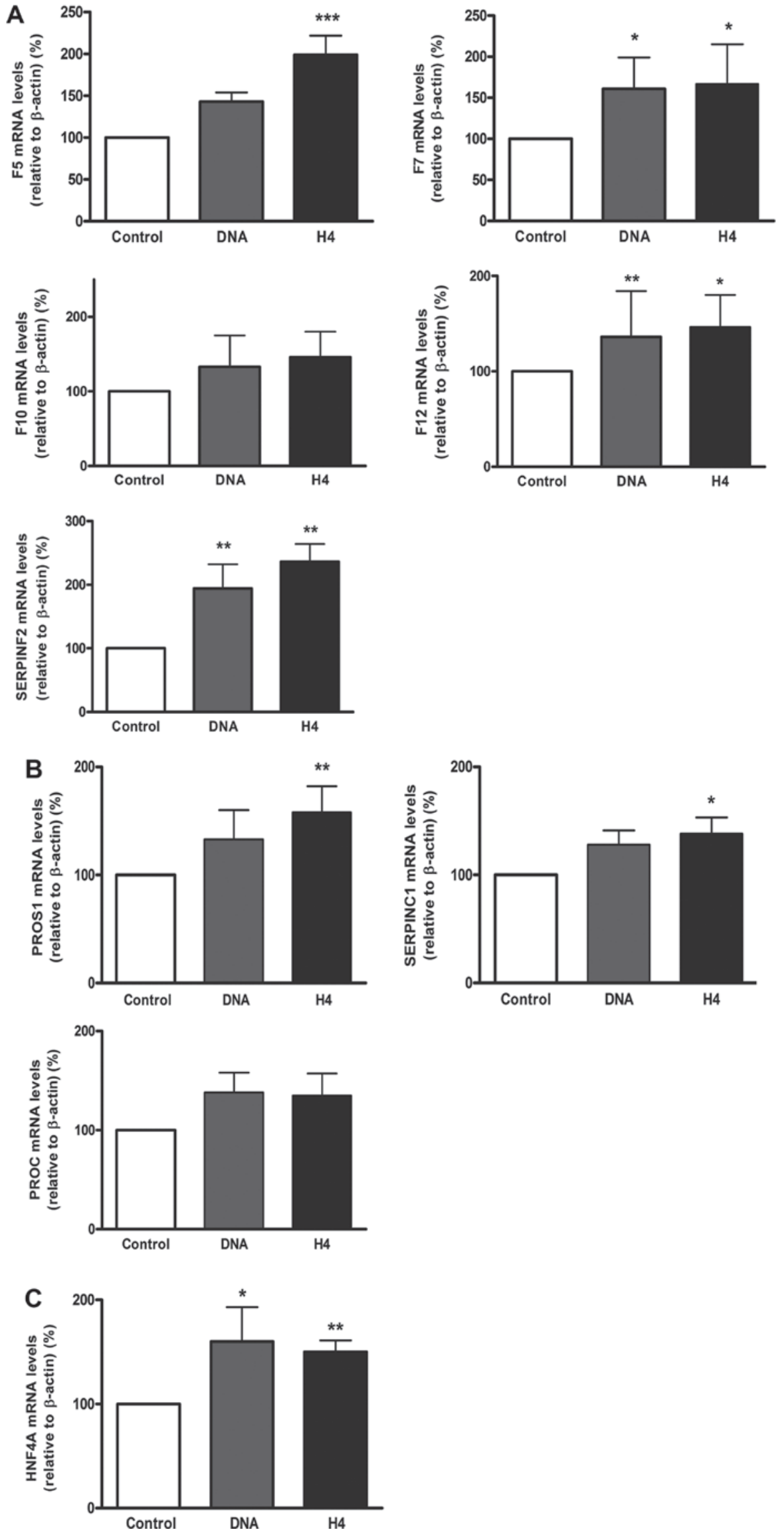

Figure 1. Neutrophil extracellular trap components increased coagulation gene expression in liver cells in vitro. The expression of (A) coagulant genes $F 5, F 7$, F10, F12, SERPINF2, (B) anticoagulant genes PROS1, SERPINC1, PROC and (C) HNF4A were measured in HepG2 cells incubated with DNA (50 ng/ml) or $\mathrm{H} 4(20 \mu \mathrm{g} / \mathrm{ml})$ for $24 \mathrm{~h}$. All data are presented as the mean \pm standard error of the mean of 3 experiments performed in triplicate. ${ }^{*} \mathrm{P}<0.05,{ }^{* *} \mathrm{P}<0.01$ and ${ }^{* * * *} \mathrm{P}<0.001$ vs. Control. F5/7/12, Factor V/VII/XII; SERPINF2, serpin family F member 2; PROC, protein C; PROS1, protein S; SERPINC1, serpin family C member 1; HNF4A, hepatocyte nuclear factor $4 \alpha$; 4 , histone $\mathrm{H} 4$. 

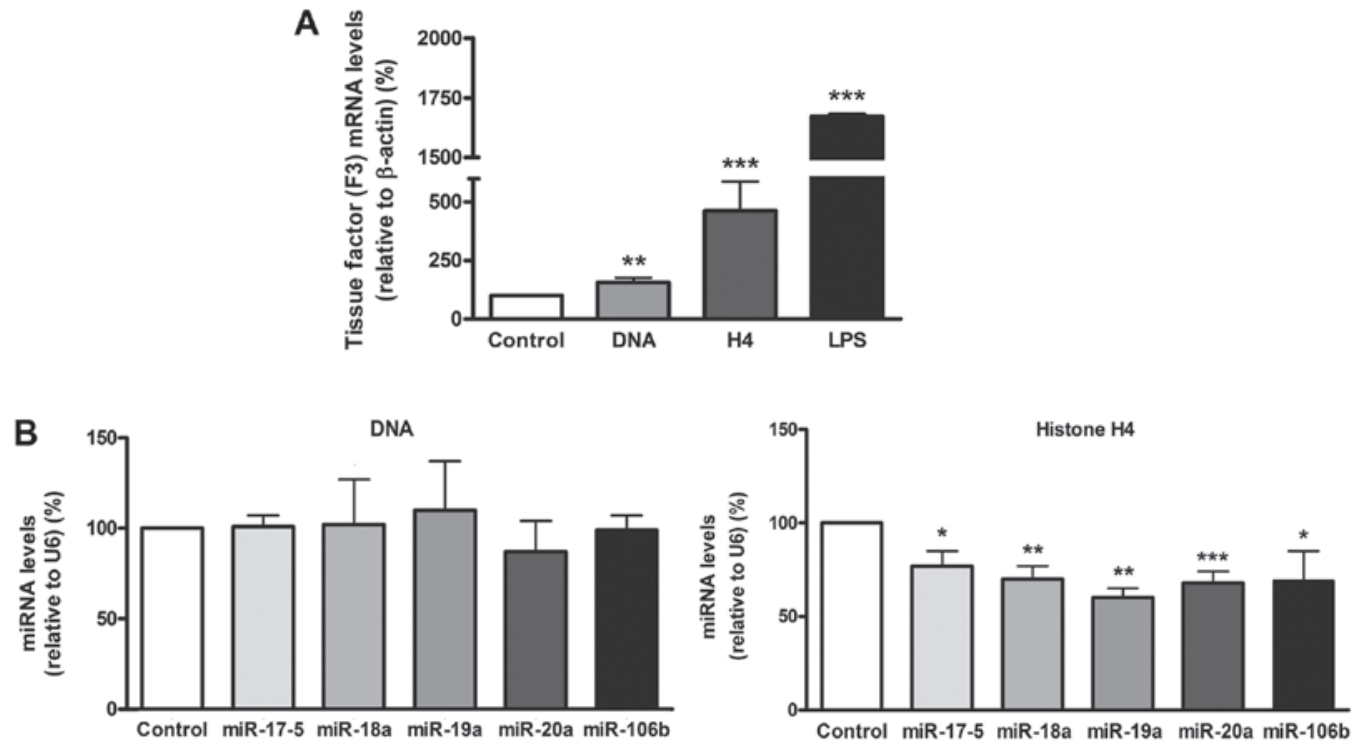

Figure 2. Expression of miR-17/92 cluster genes and target gene TF is mediated by DNA and H4 in monocytic cells in vitro. (A) THP-1 cells were treated with DNA $(50 \mathrm{ng} / \mathrm{ml})$ or $\mathrm{H} 4(20 \mu \mathrm{g} / \mathrm{ml})$ for $2 \mathrm{~h}$ and the mRNA levels of TF (F3) were determined. (B) Following the above procedure the expression of components of the miR-17/92 cluster and of miR-106b were measured as possible effector miRNAs of TF. Results are presented as the mean \pm standard error of the mean. ${ }^{*} \mathrm{P}<0.05,{ }^{* *} \mathrm{P}<0.01$ and ${ }^{* * *} \mathrm{P}<0.001$ vs. Control. TF, tissue factor; F3, factor III; miRNA/miR, microRNA; H4, histone H4; LPS, lipopolysaccharide.

recombinant $\mathrm{H} 4$ via the same procedure as for THP-1 cells and harvested after $24 \mathrm{~h}$ incubation at $37^{\circ} \mathrm{C}$ and $5 \% \mathrm{CO}_{2}$.

RNA isolation and detection of $m R N A$ expression by real-time $R T-q P C R$. Total RNA was isolated using RNAzol ${ }^{\circledR}$ RT reagent (Molecular Research Center, Inc., Cincinnati, OH) according to the manufacturer's protocol. Retrotranscription was performed using $100 \mathrm{ng}$ total RNA with MultiScribe Reverse Transcriptase and Premix Ex Taq (Probe qPCR) Master Mix (Takara Biotechnology Co., Ltd., Dalian, China) for both mRNA and miRNA PCRs.

Quantitative real-time PCR was performed using TaqMan Gene Expression Assays (Applied Biosystems; Thermo Fisher Scientific) with gene-specific primers (for F5: Hs00914120_m1; for F7: Hs01551992_m1; for F10: Hs00984443_m1; for F12: Hs00166821; for PROC: Hs00165584_m1; for PROS1: Hs00165590_m1; for SERPINC1: Hs00166654_m1; for serpin family F member 2 (SERPINF2): Hs00168989_m1; for hepatocyte nuclear factor $4 \alpha$ (HNF4A): Hs00230853_m1; and for $\beta$-actin $(A C T B)$ : Hs99999903_m1; Thermo Fisher Scientific, Inc.). PCRs were performed on a Light-Cycler 480 Real-Time PCR system (Roche Applied Science, Penzberg, Germany) with the following thermocycling conditions: A preincubation step at $95^{\circ} \mathrm{C}$ for $30 \mathrm{sec}, 40$ cycles of amplification with $3 \mathrm{sec}$ at $95^{\circ} \mathrm{C}$ and $20 \mathrm{sec}$ at $60^{\circ} \mathrm{C}$, and finally, a cooling step at $40^{\circ} \mathrm{C}$ for $30 \mathrm{sec}$. Data were analysed using the comparative threshold cycle method ( $2^{-\Delta \Delta \mathrm{Cq}}$ method) (29) with $A C T B$ as an endogenous reference control for quantification and normalization. To quantify the levels of miRNAs, TaqMan Gene Expression Assays (Thermo Fisher Scientific) were used with gene-specific primers for hsa-miR-17-5, hsa-miR-18a, hsa-miR-19a, hsa-miR-20a and hsa-miR-106b. U6 snRNA was used as an endogenous control (Thermo Fisher Scientific, Inc.).

Statistical analysis. All data are presented as the mean \pm standard error. Experiments were performed in triplicate and repeated three times. Statistical differences between groups were assessed by the non-parametric Mann-Whitney U test using GraphPad Prism 6 software (GraphPad Software Inc., La Jolla, CA). P<0.05 was considered to indicate statistical significance.

\section{Results}

H4 and DNA induce the expression of coagulation factors. To study the influence of NET components on the expression of coagulation factors in human liver, HepG2 cells were incubated with $\mathrm{H} 4$ or DNA, and the mRNA levels of 8 genes related to coagulation (F5, F7, F10, F12, PROC, PROS1, SERPINC1 and SERPINF2) were quantified.

It was identified that each DAMP induced significant increases in the expression of the different factors, both coagulant (F5, F7, F12 and SERPINF2; Fig. 1A) and anticoagulant (PROS1 and SERPINC1; Fig. 1B), though H4 consistently induced a marginally greater upregulation than DNA, when compared with the cells without treatment. For F10 and PROC, a trend towards an increase in expression was observed with each DAMP but without statistical significance.

H4 and DNA upregulate the expression of HNF4A. Since the association between HNF4A and the expression of different coagulation factors, including Protein S, Protein C and antithrombin, has previously been described (28-30), the present study quantified the levels of HNF4A mRNA following incubation with $\mathrm{H} 4$ or DNA. It was observed that each agonist upregulated the expression of $H N F 4 A$ to a significant and similar extent (Fig. 1C).

$H 4$ causes a decrease in miR-17/92 cluster expression. The next aim was to confirm the influence of NET components on the expression of TF and the involvement of the miR-17/92 cluster in this regulation. THP-1 cells were incubated with 
DNA or H4 and the levels of TF mRNA, and of several of the miRNAs included in the miR-17/92 cluster (miR-17-5, -18a, $-19 \mathrm{a}$ and -20a) and its paralog miR-106b, were assessed. LPS, was used as a positive control only for TF, to ensure its expression (33).

It was confirmed that both DNA and H4 significantly increased the expression of $T F$, with a higher increase observed when using H4 (Fig. 2A). Levels of the selected miRNA did not vary when incubating THP-1 cells with DNA (Fig. 2B, left panel), while following the treatment with $\mathrm{H} 4$, all the studied miRNAs significantly decreased in comparison with the negative control (Fig. 2B, right panel).

\section{Discussion}

In recent years, research into the pathogenicity of DAMPs has increased, and several reports have described a prothrombotic role for histones and DNA $(12,14,34,35)$. In the present study, this hypothesis was further supported by demonstrating that $\mathrm{H} 4$ and DNA induced the transcription of several coagulation factors. Specifically, the mRNA levels of F7, F12 and SERPINF2 (encoding $\alpha 2$-antiplasmin) were significantly upregulated by DNA and H4, while the mRNA levels of F5, PROS1 and SERPINC1 (encoding antithrombin) were upregulated only by $\mathrm{H} 4$. In the search of a possible mechanism for this effect, HNF4 $\alpha$ was selected as a suitable candidate. It has been demonstrated that this hepatic transcription factor is implicated in the transcription of numerous coagulation genes including F5, F7, F12, SERPINF2 and SERPINC1 $(31,32,36)$ among others. In the current study, it was hypothesized that the observed increase in HNF4A expression may be responsible for the increase in the expression of certain coagulant factors induced by $\mathrm{H} 4$ and DNA, although a direct effect of these DAMPs on the overexpression of hemostatic factors cannot be discarded (37). Limited information is available concerning the mechanisms implicated in the action of $\mathrm{H} 4$ and DNA on different cells or tissues. As mentioned, normal primary hepatocytes and primary monocytes would have been optimal models to study the effect of NETs on the expression of coagulation factors, but due to the variability between individuals that may affect the interpretation of results, the experiments were performed with cell lines that are well characterized and yield homogeneous results. It should also be noted that in 2009 the phenotype of HepG2 was described as hepatoblastoma instead of hepatocellular carcinoma (38), but this misidentification is not expected to affect interpretations in the current study.

To date, one of the sole proposed mechanisms implicated in TF expression induced by histones in monocytes is the activation of the TLR2-4/nuclear factor- $\kappa \mathrm{B}$ pathway. In that report, it was demonstrated that the selective blockade of TLR 2 or TLR4 inhibited the overexpression of TF following activation with H4, among other histones (13). Notably, the expression of TLR4 has been reported in hepatocytes and it may be implicated in the overexpression of hemostatic factors and/or HNF4 $\alpha$ as well as TF (39). Additional studies using animal models may aid to define if these changes in the coagulant state may occur in vivo and if overexpression of hemostatic factors is also detectable in plasma following a challenge with DNA or H4.
miRNAs have been recently associated with the regulation of several hemostatic factors (40). In particular, coagulation factors including fibrinogen, factor XI and tissue factor pathway inhibitor are regulated by miRNAs (41-43). As another key element, TF has also been demonstrated to be regulated by miRNAs (17). Thus, in the present study it was hypothesized that another possible effect explaining the increased expression of TF by DAMPs in monocytes may be an alteration of miRNA expression. In this regard, it was identified that, following the treatment with $\mathrm{H} 4$, the decrease of miRNAs targeting TF was significant. Philippe et al demonstrated that activation of TLR 2 in synoviocytes by bacterial lipoproteins (44) or of TLR4 by LPS (45) decreased the expression of miR-19a/b and miR-20a, respectively. These results are in accord with the present findings, although the mechanism by which these miRNAs are decreased by DAMPs is still unknown. Meanwhile, DNA had no effect on the expression of miRNAs in the miR-17-92 cluster, suggesting that the upregulation of TF by DNA is independent of miR-17-92 and other unknown mechanisms are involved.

In conclusion, the present results indicated that $\mathrm{H} 4$ and, to a lesser extent, DNA cause an increase in the mRNA expression of various coagulation factors. This upregulation may alter the hemostatic balance and may explain the prothrombotic effect of histones and DNA, although this requires further confirmation. Additionally, both DNA and H4 triggered an increase in HNF4A mRNA expression that may indicate its partial involvement in the regulation of clotting factors mediated by DAMPs. Finally, it was determined that $\mathrm{H} 4$ could induce a decrease in the expression of certain miRNAs of the miR-17/92 cluster, which may partially explain the upregulation of the expression of TF induced by $\mathrm{H} 4$.

\section{Acknowledgements}

Not applicable.

\section{Funding}

The current study was supported by research grants from the Instituto de Salud Carlos III and Fondo Europeo de Desarrollo Regional (FEDER; grant no. PI17/00051) and the Fundación Séneca (grant no. 19873/GERM/15). ABA has a research fellowship from Sociedad Española de Trombosis y Hemostasia (SETH)

\section{Availability of data and materials}

Data and material related to this manuscript are available from the corresponding authors on reasonable request.

\section{Authors' contributions}

RGC and CM conceptualized the study. AMDLRG, RGC and $\mathrm{CM}$ were responsible for data acquisition. AMDR, AAC and ABA performed the analyses of the data. AMDLRG, AA, ABA, NGB, VV, RGC and CM performed the experiments. NGB provided technical support in data acquisition. AMDLRG, AA and ABA drafted the manuscript. RGC, VV and $\mathrm{CM}$ reviewed and edited the manuscript. 


\section{Ethics approval and consent to participate}

All subjects who met eligibility criteria were enrolled after providing written informed consent. The study was approved by the Ethical Committee of Morales Meseguer University Hospital, Murcia, Spain (approval no., 20/14) and performed in accordance with the ethical standards laid down in the 1964 Declaration of Helsinki and its subsequent amendments.

\section{Patient consent for publication}

All subjects gave their consent for the publication of associated data.

\section{Competing interests}

The authors declare that they have no competing interests.

\section{References}

1. Engelmann B and Massberg S: Thrombosis as an intravascular effector of innate immunity. Nat Rev Immunol 13: 34-45, 2013.

2. Swystun LL and Liaw PC: The role of leukocytes in thrombosis. Blood 128: 753-762, 2016.

3. Urban CF, Ermert D, Schmid M, Abu-Abed U, Goosmann C, Nacken W, Brinkmann V, Jungblut PR and Zychlinsky A: Neutrophil extracellular traps contain calprotectin, a cytosolic protein complex involved in host defense against Candida albicans. PLoS Pathog 5: e1000639, 2009.

4. Zawrotniak M and Rapala-Kozik M: Neutrophil extracellular traps (NETs) - formation and implications. Acta Biochim Pol 60: 277-284, 2013

5. Rao AN, Kazzaz NM and Knight JS: Do neutrophil extracellular traps contribute to the heightened risk of thrombosis in inflammatory diseases? World J Cardiol 7: 829-842, 2015.

6. Lee KH, Kronbichler A, Park DD, Park Y, Moon H, Kim H, Choi JH, Choi Y, Shim S, Lyu IS, et al: Neutrophil extracellular traps (NETs) in autoimmune diseases: A comprehensive review. Autoimmun Rev 16: 1160-1173, 2017.

7. Knight JS, Luo W, O'Dell AA, Yalavarthi S, Zhao W, Subramanian V, Guo C, Grenn RC, Thompson PR, Eitzman DT, et al: Peptidylarginine deiminase inhibition reduces vascular damage and modulates innate immune responses in murine models of atherosclerosis. Circ Res 114: 947-956, 2014.

8. Tang S, Zhang Y, Yin SW, Gao XJ, Shi WW, Wang Y, Huang X, Wang L, Zou LY, Zhao JH, et al: Neutrophil extracellular trap formation is associated with autophagy-related signalling in ANCA-associated vasculitis. Clin Exp Immunol 180: 408-418, 2015.

9. Berger-Achituv S, Brinkmann V, Abed UA, Kühn LI, Ben-Ezra J, Elhasid R and Zychlinsky A: A proposed role for neutrophil extracellular traps in cancer immunoediting. Front Immunol 4: 48, 2013.

10. Fuchs TA, Brill A, Duerschmied D, Schatzberg D, Monestier M, Myers DD Jr, Wrobleski SK, Wakefield TW, Hartwig JH and Wagner DD: Extracellular DNA traps promote thrombosis. Proc Natl Acad Sci USA 107: 15880-15885, 2010.

11. Brill A, Fuchs TA, Savchenko AS, Thomas GM, Martinod K, De Meyer SF, Bhandari AA and Wagner DD: Neutrophil extracellular traps promote deep vein thrombosis in mice. J Thromb Haemost 10: 136-144, 2012.

12. Semeraro F, Ammollo CT, Morrissey JH, Dale GL, Friese P, Esmon NL and Esmon CT: Extracellular histones promote thrombin generation through platelet-dependent mechanisms: Involvement of platelet TLR2 and TLR4. Blood 118: 1952-1961, 2011.

13. Kim JE, Yoo HJ, Gu JY and Kim HK: Histones Induce the Procoagulant Phenotype of Endothelial Cells through Tissue Factor Up-Regulation and Thrombomodulin Down-Regulation. PLoS One 11: e0156763, 2016.

14. Ammollo CT, Semeraro F, Xu J, Esmon NL and Esmon CT: Extracellular histones increase plasma thrombin generation by impairing thrombomodulin-dependent protein $\mathrm{C}$ activation. J Thromb Haemost 9: 1795-1803, 2011.
15. Yang X, Li L, Liu J, Lv B and Chen F: Extracellular histones induce tissue factor expression in vascular endothelial cells via TLR and activation of NF- $\mathrm{kB}$ and AP-1. Thromb Res 137: 211-218, 2016.

16. Gould TJ, Lysov Z, Swystun LL, Dwivedi DJ, Zarychanski R, Fox-Robichaud AE and Liaw PC; Canadian Critical Care Translational Biology Group: Extracellular Histones Increase Tissue Factor Activity and Enhance Thrombin Generation by Human Blood Monocytes. Shock 46: 655-662, 2016.

17. Bhagirath VC, Dwivedi DJ and Liaw PC: Comparison of the Proinflammatory and Procoagulant Properties of Nuclear, Mitochondrial, and Bacterial DNA. Shock 44: 265-271, 2015.

18. Mann KG, Nesheim ME, Tracy PB, Hibbard LS and Bloom JW: Assembly of the prothrombinase complex. Biophys J 37: 106-107, 1982.

19. Krishnaswamy S: The transition of prothrombin to thrombin. J Thromb Haemost 11 (Suppl 1): 265-276, 2013.

20. O'Hara PJ, Grant FJ, Haldeman BA, Gray CL, Insley MY, Hagen FS and Murray MJ: Nucleotide sequence of the gene coding for human factor VII, a vitamin K-dependent protein participating in blood coagulation. Proc Natl Acad Sci USA 84: 5158-5162, 1987.

21. Didiasova M, Wujak L, Schaefer L and Wygrecka M: Factor XII in coagulation, inflammation and beyond. Cell Signal 51: 257-265, 2018.

22. Esmon NL, Owen WG and Esmon CT: Isolation of a membrane-bound cofactor for thrombin-catalyzed activation of protein C. J Biol Chem 257: 859-864, 1982.

23. Hayhurst GP, Lee Y-H, Lambert G, Ward JM and Gonzalez FJ: Hepatocyte nuclear factor 4alpha (nuclear receptor 2A1) is essential for maintenance of hepatic gene expression and lipid homeostasis. Mol Cell Biol 21: 1393-1403, 2001.

24. Björk I and Olson ST: Antithrombin. A bloody important serpin. Adv Exp Med Biol 425: 17-33, 1997.

25. Kettle P and Mayne EE: A bleeding disorder due to deficiency of alpha 2-antiplasmin. J Clin Pathol 38: 428-429, 1985.

26. Furie B and Furie BC: The molecular basis of blood coagulation. Cell 53: 505-518, 1988.

27. Teruel R,Pérez-Sánchez C, Corral J, Herranz MT,Pérez-Andreu V, Saiz E, García-Barberá N, Martínez-Martínez I, Roldán V, Vicente V, et al: Identification of miRNAs as potential modulators of tissue factor expression in patients with systemic lupus erythematosus and antiphospholipid syndrome. J Thromb Haemost 9: 1985-1992, 2011

28. Ramboer E, De Craene B, De Kock J, Vanhaecke T, Berx G, Rogiers V and Vinken M: Strategies for immortalization of primary hepatocytes. J Hepatol 61: 925-943, 2014.

29. Livak KJ and Schmittgen TD: Analysis of relative gene expression data using real-time quantitative PCR and the 2(- $\Delta \Delta$ C(T)) method. Methods 25: 402-408, 2001.

30. Salloum-Asfar S, Arroyo AB, Teruel-Montoya R, García-Barberá N, Roldán V, Vicente V, Martínez C and González-Conejero R: miRNA-Based Regulation of Hemostatic Factors through Hepatic Nuclear Factor-4 Alpha. PLoS One 11: e0154751, 2016.

31. Erdmann D and Heim J: Orphan nuclear receptor HNF-4 binds to the human coagulation factor VII promoter. J Biol Chem 270: 22988-22996, 1995.

32. Tarumi T, Kravtsov DV, Zhao M, Williams SM and Gailani D: Cloning and characterization of the human factor XI gene promoter: Transcription factor hepatocyte nuclear factor 4alpha (HNF-4alpha ) is required for hepatocyte-specific expression of factor XI. J Biol Chem 277: 18510-18516, 2002.

33. Brand K, Fowler BJ, Edgington TS and Mackman N: Tissue factor mRNA in THP-1 monocytic cells is regulated at both transcriptional and posttranscriptional levels in response to lipopolysaccharide. Mol Cell Biol 11: 4732-4738, 1991.

34. Xu J,Zhang X, Pelayo R, Monestier M, Ammollo CT, Semeraro F, Taylor FB, Esmon NL, Lupu F and Esmon CT: Extracellular histones are major mediators of death in sepsis. Nat Med 15: 1318-1321, 2009.

35. Noubouossie DF, Whelihan MF, Yu YB, Sparkenbaugh E, Pawlinski R, Monroe DM and Key NS: In vitro activation of coagulation by human neutrophil DNA and histone proteins but not neutrophil extracellular traps. Blood 129: 1021-1029, 2017.

36. Farsetti A, Moretti F, Narducci M, Misiti S, Nanni S, Andreoli M, Sacchi A and Pontecorvi A: Orphan receptor hepatocyte nuclear factor-4 antagonizes estrogen receptor alpha-mediated induction of human coagulation factor XII gene. Endocrinology 139: 4581-4589, 1998 . 
37. Tremp GL, Duchange N, Branellec D, Cereghini S, Tailleux A, Berthou L, Fievet C, Touchet N, Schombert B, Fruchart JC, et al: A 700-bp fragment of the human antithrombin III promoter is sufficient to confer high, tissue-specific expression on human apolipoprotein A-II in transgenic mice. Gene 156: 199-205, 1995.

38. López-Terrada D, Cheung SW, Finegold MJ and Knowles BB Hep G2 is a hepatoblastoma-derived cell line. Hum Pathol 40: $1512-1515,2009$

39. Lee YS, Kim YH, Jung YS, Kim KS, Kim DK, Na SY, Lee JM, Lee $\mathrm{CH}$ and Choi HS: Hepatocyte Toll-like receptor 4 mediates lipopolysaccharide-induced hepcidin expression. Exp Mol Med 49: e408, 2017.

40. Teruel-Montoya R, Rosendaal FR and Martínez C: MicroRNAs in hemostasis. J Thromb Haemost 13: 170-181, 2015.

41. Fish RJ and Neerman-Arbez M: Fibrinogen gene regulation. Thromb Haemost 108: 419-426, 2012.

42. Salloum-Asfar S, Teruel-Montoya R, Arroyo AB, García-Barberá N, Chaudhry A, Schuetz E, Luengo-Gil G, Vicente V, González-Conejero R and Martínez C: Regulation of coagulation factor XI expression by microRNAs in the human liver. PLoS One 9: e111713, 2014.
43. B Arroyo A, Salloum-Asfar S,Pérez-Sánchez C, Teruel-Montoya R, Navarro S, García-Barberá N, Luengo-Gil G, Roldán V, Hansen JB, López-Pedrera $\mathrm{C}$, et al: Regulation of TFPI $\alpha$ expression by miR-27a/b-3p in human endothelial cells under normal conditions and in response to androgens. Sci Rep 7: 43500, 2017.

44. Philippe L, Alsaleh G, Suffert G, Meyer A, Georgel P, Sibilia J, Wachsmann D and Pfeffer S: TLR2 expression is regulated by microRNA miR-19 in rheumatoid fibroblast-like synoviocytes. J Immunol 188: 454-461, 2012.

45. Philippe L, Alsaleh G, Pichot A, Ostermann E, Zuber G, Frisch B, Sibilia J, Pfeffer S, Bahram S, Wachsmann D, et al: miR-20a regulates ASK1 expression and TLR4-dependent cytokine release in rheumatoid fibroblast-like synoviocytes. Ann Rheum Dis 72: 1071-1079, 2013. 